\title{
Thalassomonas ganghwensis sp. nov., isolated from tidal flat sediment
}

Correspondence

Jongsik Chun

jchun@snu.ac.kr

\author{
Hana Yi, ${ }^{1}$ Kyung Sook Bae ${ }^{2}$ and Jongsik Chun ${ }^{1}$ \\ ${ }^{1}$ School of Biological Sciences, Seoul National University, 56-1 Shillim-dong, Kwanak-gu, \\ Seoul 151-742, Korea \\ ${ }^{2}$ Korean Collection for Type Cultures, Korea Research Institute of Bioscience and \\ Biotechnology, Yusung, PO Box 115, Taejon 305-600, Korea
}

\begin{abstract}
A Gram-negative, aerobic, halophilic bacterium, designated strain $\mathrm{JC} 2041^{\top}$, was isolated from a sediment sample of getbol, the Korean tidal flat. Results of $16 \mathrm{~S}$ rDNA sequence analyses indicated a moderate relationship to Thalassomonas viridans within the $\gamma$-Proteobacteria (94.9\% similarity). Depending on the tree-making algorithm used, the isolate either formed a monophyletic clade with $T$. viridans or was recovered as a sister group of a class containing the genera Thalassomonas and Colwellia. Phenotypic features of the getbol isolate were similar to those of $T$. viridans, but several physiological and chemotaxonomic properties, including nitrate reduction, amylase, lecithinase, Tweenase and utilization of 13 carbon sources, distinguished strain $\mathrm{JC} 2041^{\top}$ from $T$. viridans. The polyphasic data presented in this study indicate that the isolate should be classified as a novel species in the genus Thalassomonas. The name Thalassomonas ganghwensis sp. nov. is therefore proposed for the getbol isolate; the type strain is $\mathrm{JC} 2041^{\top}$ $\left(=\right.$ IMSNU $14005^{\top}=$ KCTC $12041^{\top}=$ DSM $\left.15355^{\top}\right)$.
\end{abstract}

In our recent study on the culturable aerobic bacterial community in getbol (Korean tidal flat), a large number of novel bacterial strains was isolated from Ganghwa Island in Korea (Yi \& Chun, 2002). Five of these isolates were members of the $\gamma$-Proteobacteria, including strain JC2041 ${ }^{\mathrm{T}}$ and two strains of Zooshikella ganghwensis (Yi et al., 2003). In this study, the polyphasic characterization of isolate $\mathrm{JC} 2041^{\mathrm{T}}$ is presented; the name Thalassomonas ganghwensis sp. nov. is proposed for this isolate.

Strain $\mathrm{JC} 2041^{\mathrm{T}}$ was isolated from a tidal flat sediment sample $\left(37^{\circ} 36^{\prime} 22 \cdot 3^{\prime \prime} \mathrm{N} ; 126^{\circ} 22^{\prime} 59 \cdot 4^{\prime \prime} \mathrm{E}\right)$ using MR2A [R2A (Difco) supplemented with the artificial sea water of Lyman \& Fleming (1940)] at $25^{\circ} \mathrm{C}$ and routinely maintained on MA (marine agar 2216; Difco) at $30^{\circ} \mathrm{C}$. Thalassomonas viridans DSM $13754^{\mathrm{T}}$ was used as a reference strain and grown on $\mathrm{MA}$ at $30^{\circ} \mathrm{C}$.

Bacterial DNA preparation and PCR amplification and sequencing of $16 \mathrm{~S}$ rDNA were carried out as described previously (Chun \& Goodfellow, 1995). The resultant sequence of strain JC2041 ${ }^{\mathrm{T}}$ was aligned manually against sequences obtained from GenBank. Phylogenetic trees were inferred using the Fitch-Margoliash (Fitch \& Margoliash,

Published online ahead of print on 15 August 2003 as DOI 10.1099/ ijs.0.02748-0.

The GenBank accession number for the $16 \mathrm{~S}$ rDNA sequence of strain $\mathrm{JC} 2041^{\top}$ is AY194066.
1967), maximum-likelihood (Felsenstein, 1993), maximumparsimony (Fitch, 1972) and neighbour-joining (Saitou \& Nei, 1987) methods. Evolutionary distance matrices were generated according to Jukes \& Cantor (1969). The resultant tree topologies were evaluated in bootstrap analyses (Felsenstein, 1985) of the neighbour-joining method based on 1000 resamplings. The alignment and phylogenetic analyses were carried out using PHYDIT (available at http:// plaza.snu.ac.kr/ jchun/phydit/) and PAUP 4.0 (Swofford, 1998) as described previously (Chun et al., 2000).

A nearly complete $16 \mathrm{~S}$ rDNA sequence of strain $\mathrm{JC}^{2} 2041^{\mathrm{T}}$ was obtained (1408 bp) and used for an initial BLAST search against GenBank. The result clearly indicated that the getbol isolate was a member of the $\gamma$-Proteobacteria. The newly determined sequence was then aligned manually against representatives of the $\gamma$-Proteobacteria based on the secondary structure of bacterial $16 \mathrm{~S}$ rRNA. Strain JC2041 ${ }^{\mathrm{T}}$ showed highest $16 \mathrm{~S}$ rDNA sequence similarity to T. viridans CECT $5083^{\mathrm{T}}$ (94.9\%); the next highest similarities were observed with the genera Colwellia (93.093.4\%), Idiomarina (90.9-91.1\%) and Pseudoalteromonas $(88 \cdot 4-90 \cdot 2 \%)$.

These relationships were also observed in phylogenetic trees, as shown in Fig. 1. The clade containing strain JC2041 ${ }^{\mathrm{T}}$, T. viridans and Colwellia species had $100 \%$ bootstrap support and was obtained by all tree-making methods. However, the isolate either formed a monophyletic clade with $T$. viridans (in Fitch-Margoliash and 


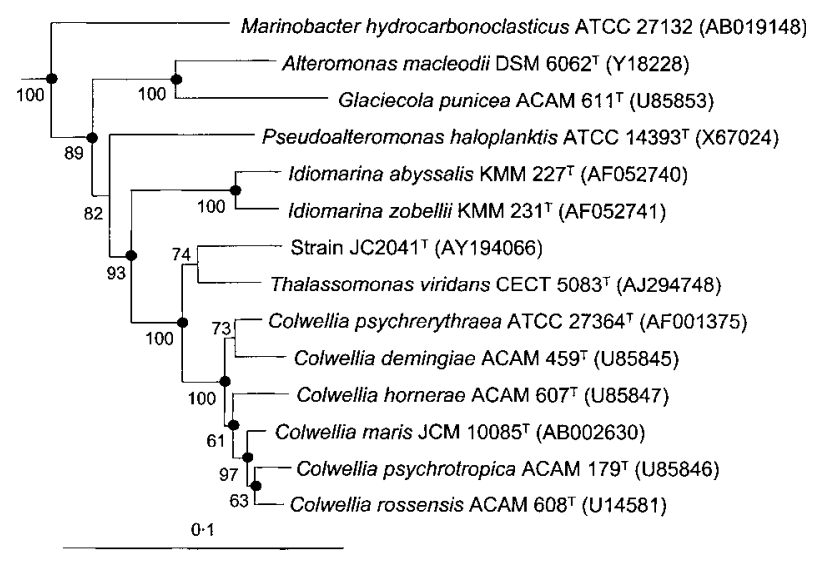

Fig. 1. Neighbour-joining tree based on nearly complete $16 \mathrm{~S}$ rDNA sequences showing relationships among strain JC2041 ${ }^{\top}$ and members of the $\gamma$-Proteobacteria. Numbers at nodes are levels of bootstrap support (\%) based on neighbour-joining analyses of 1000 resampled datasets; solid circles indicate that the corresponding nodes (groupings) are also recovered in Fitch-Margoliash, maximum-likelihood and maximum-parsimony trees. Helicobacter pylori ATCC $43504^{\top}$ (U01330) was used as an outgroup (not shown). Bar, $0 \cdot 1 \mathrm{nt}$ substitutions per position.

neighbour-joining trees) or was recovered as a sister group to a clade containing $T$. viridans and Colwellia species (in maximum-parsimony and maximum-likelihood trees), depending on the tree-making algorithm used.

Cultural characteristics were studied using several bacteriological growth media. Although strain JC2041 ${ }^{\mathrm{T}}$ was isolated on MR2A, it grew better on MA, CSY-3 (Sawabe et al., 1998) and SMM (Shioi's marine medium; Shiba, 1992). The test strain retained viability for about 20 days on $\mathrm{MA}$ at $30^{\circ} \mathrm{C}$. The isolate was strictly halophilic, requiring media containing 1-8\% (w/v) artificial sea salts (Sigma) for growth (optimum of $2-4 \%$ sea salts). It was unable to grow on modified CSY-3 medium containing 0-15\% (w/v) $\mathrm{NaCl}$ alone. Growth on MA was observed in the $\mathrm{pH}$ range $7-11$ and optimal growth occurred at $\mathrm{pH} 7-8$. The temperature range for growth was $15-40{ }^{\circ} \mathrm{C}$; optimum growth was observed at $35^{\circ} \mathrm{C}$. No growth was detected under anaerobic conditions created by a GasPack system (BBL).

The morphology of cells grown on MA at $30{ }^{\circ} \mathrm{C}$ was examined using phase-contrast microscopy, SEM and TEM. After 1 day incubation, colonies were approximately $2 \mathrm{~mm}$ in diameter; they reached a maximum diameter of 4-5 mm after 4 days. Colonies were circular, convex with an entire margin, glistening, translucent, viscid and yellowish. When grown on YBM [BM (basal medium; Baumann et al., 1972) containing $0.01 \%$ yeast extract] supplemented with $0 \cdot 1 \%$ tyrosine, strain $\mathrm{JC} 2041^{\mathrm{T}}$ produced diffusible brown pigments on an agar plate. Cells in late exponential phase were rod-shaped with a polar flagellum and approximately $1 \cdot 5-2 \cdot 3 \mu \mathrm{m}$ long by $0 \cdot 5-0 \cdot 8 \mu \mathrm{m}$ wide. Spore formation was not observed.
Carbon source utilization was tested on BM supplemented with $0 \cdot 1 \%$ yeast extract. Other physiological properties were tested using standard procedures, as described previously (Yi et al., 2003). These reactions, as well as some other properties of strain $\mathrm{JC} 2041^{\mathrm{T}}$, are indicated in the species description. The test strain could be differentiated from $T$. viridans and phylogenetically related genera by a number of characteristics (Table 1).

Chemotaxonomic characteristics were determined for cells grown at $30{ }^{\circ} \mathrm{C}$ for 2 days on $\mathrm{MA}$ or in $\mathrm{MB}$ (marine broth 2216). Analysis of fatty acid methyl esters was performed by GLC according to the Microbial Identification (MIDI) system. Saturated and monounsaturated fatty acids, namely $16: 0(22 \cdot 3 \%)$ and $18: 1 \omega 7 c(11 \cdot 3 \%)$, were the most abundant, together with a mixture of $16: 1 \omega 7 c$ and i-15:0 2-OH (20.6\%; the MIDI system could not differentiate between these two fatty acids). Smaller, albeit substantial, amounts of $10: 0(4 \cdot 9 \%), \mathrm{i}-16: 0(7 \cdot 1 \%), 16: 1 \omega 9 c$ $(4 \cdot 7 \%)$ and $17: 1 \omega 8 c(4 \cdot 4 \%)$ were also detected. This fatty acid composition was most similar to that observed in the genus Thalassomonas and clearly differentiated the isolate from other phylogenetically related genera (Table 1). Only minor quantitative differences in amounts of $15: 0,16: 0$, $17: 1 \omega 8 c$ and $18: 1 \omega 7 c$ were found between our isolate and T. viridans.

Isoprenoid quinones of the test strain and T. viridans DSM $13754^{\mathrm{T}}$ were isolated from freeze-dried biomass according to Minnikin et al. (1984), purified on preparative TLC (silica gel $\mathrm{F}_{254}$; Merck) and analysed by HPLC (Waters) equipped with a reverse-phase column (Spherisorb ODS-2 80; Waters) as described by Collins (1985). Ubiquinone- 8 (Q-8) was the predominant isoprenoid quinone in both strains. The genus Colwellia is also reported to contain Q-8 as its major quinone (Yumoto et al., 1998).

The DNA G $+\mathrm{C}$ content was determined by HPLC of deoxyribonucleosides as described by Mesbah et al. (1989) using a reverse-phase column (Supelcosil LC-18-S; Supelco). The $\mathrm{G}+\mathrm{C}$ content of strain $\mathrm{JC} 2041^{\mathrm{T}}$ was $42 \mathrm{~mol} \%$.

Although the phylogenetic position of strain $\mathrm{JC} 041^{\mathrm{T}}$ is somewhat different depending on the tree building method used for analysis, the close relationship of our isolate to $T$. viridans was obvious in sequence similarity comparisons and phylogenetic trees based on 16S rDNA. Moreover, our isolate showed phenotypic traits that were similar to those of $T$. viridans, rather than to Colwellia species. However, the low sequence similarity, $94.9 \%$, and many physiological and chemotaxonomic properties, i.e. nitrate reduction, amylase, lecithinase, Tweenase and utilization of 13 carbon sources, distinguished our isolate from $T$. viridans (Table 1). Based on the polyphasic evidence presented in this study, it is fair to conclude that strain JC2041 ${ }^{\mathrm{T}}$ merits novel species status in the genus Thalassomonas. The name Thalassomonas ganghwensis sp. nov. is proposed for strain JC2041 ${ }^{\mathrm{T}}$. 
Table 1. Characteristics that differentiate strain $\mathrm{JC} 2041^{\top}$ from $T$. viridans and phylogenetically related genera

Strain/taxa: 1, strain $\mathrm{JC}_{2041}{ }^{\mathrm{T}}$; 2, Thalassomonas viridans; 3, genus Colwellia; 4, genus Idiomarina. Data were taken from this and earlier studies (Bowman et al., 1998; Deming et al., 1988; Ivanova et al., 2000; Macián et al., 2001; Yumoto et al., 1998). +, Positive reaction; -, negative reaction; W, weakly positive; $\mathrm{V}$, variable; $\mathrm{V}+$, more than half of the species are positive and the type species is positive; $\mathrm{V}-$, fewer than half of the species are negative and the type species is negative; ND, no data available; PUFA, polyunsaturated fatty acids.

\begin{tabular}{|c|c|c|c|c|}
\hline Characteristic & 1 & 2 & 3 & 4 \\
\hline Pigment & Yellow & Green & Red, white & Yellow \\
\hline Sea salts requirement & + & + & $\mathrm{V}$ & - \\
\hline Oxygen requirement & Strict aerobe & Strict aerobe & Facultative anaerobe & Strict aerobe \\
\hline \multicolumn{5}{|l|}{ Growth at: } \\
\hline $4^{\circ} \mathrm{C}$ & - & - & + & + \\
\hline $37^{\circ} \mathrm{C}$ & + & + & - & - \\
\hline Nitrate reduction & + & - & + & ND \\
\hline Carbohydrate fermentation & - & - & $\mathrm{v}+$ & - \\
\hline Amylase & - & + & $\mathrm{v}+$ & - \\
\hline$\beta$-Galactosidase & + & + & - & ND \\
\hline Chitinase & - & - & $\mathrm{V}+$ & $\mathrm{V}$ \\
\hline DNase & + & + & $\mathrm{V}-$ & + \\
\hline Lecithinase & - & + & $\mathrm{ND}$ & $\mathrm{ND}$ \\
\hline Tweenase & + & - & $\mathrm{v}+$ & + \\
\hline \multicolumn{5}{|l|}{ Utilization of: } \\
\hline Acetate & + & - & + & $\mathrm{V}$ \\
\hline D-Cellobiose & - & + & - & $\mathrm{ND}$ \\
\hline D-Fructose & - & $\mathrm{w}$ & $\mathrm{v}-$ & - \\
\hline D-Galactose & + & - & - & ND \\
\hline D-Glucose & + & $\mathrm{w}$ & $\mathrm{V}$ & - \\
\hline D-Ribose & - & + & ND & ND \\
\hline Glycine & $\mathrm{W}$ & - & ND & ND \\
\hline L-Arginine & - & + & $\mathrm{V}$ & ND \\
\hline L-Asparagine & $\mathrm{W}$ & - & $\mathrm{V}$ & ND \\
\hline L-Lysine & $\mathrm{W}$ & - & ND & - \\
\hline L-Tyrosine & + & - & ND & + \\
\hline Succinate & $\mathrm{W}$ & - & + & + \\
\hline Tartrate & $\mathrm{W}$ & - & $\mathrm{V}$ & ND \\
\hline DNA G + C content $(\mathrm{mol} \%)$ & 42 & 48 & $35-42$ & $48-50$ \\
\hline \multicolumn{5}{|l|}{ Fatty acids (\% of total): } \\
\hline i- $15: 0$ & - & - & - & $33 \cdot 7-40 \cdot 6$ \\
\hline $15: 0$ & $1 \cdot 2$ & $6 \cdot 0-11 \cdot 1$ & $0 \cdot 9-14 \cdot 3$ & - \\
\hline $\mathrm{i}-16: 0$ & $7 \cdot 1$ & $<1 \cdot 0$ & $0 \cdot 0-10 \cdot 3$ & - \\
\hline $16: 1 \omega 9 c$ & $4 \cdot 7$ & - & $0 \cdot 0-20 \cdot 0$ & $<1 \cdot 0$ \\
\hline $16: 1 \omega 7 c / \mathrm{i}-15: 02-\mathrm{OH}$ & $20 \cdot 6$ & $21 \cdot 2-28 \cdot 4$ & $6 \cdot 0-56 \cdot 8$ & $7 \cdot 0-8 \cdot 3$ \\
\hline $16: 0$ & $22 \cdot 3$ & $11 \cdot 2-13 \cdot 7$ & $13 \cdot 5-33 \cdot 2$ & $4 \cdot 6-6 \cdot 3$ \\
\hline $\mathrm{i}-17: 0$ & - & - & - & $11 \cdot 9-12 \cdot 5$ \\
\hline $17: 1 \omega 8 c$ & $4 \cdot 4$ & $14 \cdot 1-19 \cdot 7$ & $0 \cdot 0-5 \cdot 6$ & $0 \cdot 8-1 \cdot 1$ \\
\hline $18: 1 \omega 7 c$ & $11 \cdot 3$ & $3 \cdot 2-6 \cdot 1$ & $0 \cdot 0-4 \cdot 2$ & $5 \cdot 9-6 \cdot 7$ \\
\hline PUFA & - & - & $0 \cdot 8-9 \cdot 5$ & - \\
\hline
\end{tabular}

\section{Description of Thalassomonas ganghwensis} sp. nov.

Thalassomonas ganghwensis (gang.hwen'sis. N.L. fem. adj. ganghwensis named after Ganghwa Island in Korea, the geographical origin of the type strain).
Gram-negative. Oxidase- and catalase-positive. Strictly aerobic, chemoheterotrophic and halophilic. Cells are rod-shaped $(1 \cdot 5-2 \cdot 3 \times 0 \cdot 5-0 \cdot 8 \mu \mathrm{m})$ and motile with a polar flagellum. Colonies are circular, convex, glistening, translucent, viscid, yellowish and have an entire margin on 
MA. Does not grow without sea water or the addition of artificial sea salts (1-8\%) to the medium. Grows at $15-40{ }^{\circ} \mathrm{C}$ and $\mathrm{pH} 7-11$. Optimal growth is observed at $35^{\circ} \mathrm{C}, \mathrm{pH} 7-8$ and $2-4 \%$ artificial sea salts. Abundant growth is observed on MA, CSY-3 and SMM media. Spores are not formed. Reduces nitrate to nitrite. Negative for fermentation of glucose. Decomposes casein, DNA, aesculin, gelatin and Tween 80 , but not agar, alginate, cellulose, chitin, lecithin or starch. Produces $\beta$-galactosidase, but not arginine dihydrolase, lysine decarboxylase, ornithine decarboxylase, urease, acetoin, fluorescein, $\mathrm{H}_{2} \mathrm{~S}$, indole or polyhydroxybutyrate. Produces alkaline phosphatase, esterase (C4), leucine arylamidase, valine arylamidase, acid phosphatase and naphthol-AS-BI-phosphohydrolase, but not esterase lipase (C8), lipase (C14), cystine arylamidase, trypsin, $\alpha$-chymotrypsin, $\alpha$-galactosidase, $\beta$-galactosidase, $\beta$ glucuronidase, $\alpha$-glucosidase, $\beta$-glucosidase, $N$-acetyl- $\beta$ glucosaminidase, $\alpha$-mannosidase or $\alpha$-fucosidase. Utilizes acetate, D-galactose, D-glucose and L-tyrosine as sole carbon sources. Glycine, L-asparagine, L-lysine, succinate and tartrate are weakly utilized. Does not utilize acetamide, benzoate, citrate, D-cellobiose, D-fructose, D-mannitol, D-mannose, D-raffinose, D-ribose, D-salicin, D-sorbitol, D-trehalose, D-xylose, ethanol, inositol, inulin, 2-propanol, lactose, L-arginine, L-ascorbate, L-ornithine, L-rhamnose, polyethylene glycol, salicylate or thiamin. The major isoprenoid quinone is ubiquinone-8. The major fatty acids are $16: 0,18: 1 \omega 7 c$ and a mixture of $16: 1 \omega 7 c$ and i- $15: 0$ 2-OH.

The type strain, JC2041 ${ }^{\mathrm{T}} \quad\left(=\mathrm{IMSNU} \quad 14005^{\mathrm{T}}=\mathrm{KCTC}\right.$ $12041^{\mathrm{T}}=$ DSM $15355^{\mathrm{T}}$ ), was isolated from sediment of getbol, the Korean tidal flat. The DNA G $+\mathrm{C}$ content of the type strain is $42 \mathrm{~mol} \%$.

\section{Acknowledgements}

We are grateful to Dr J. P. Euzéby for help with nomenclature. This work was supported by the Korea Research Foundation (project no. KRF-2001-041-D00207).

\section{References}

Baumann, L., Baumann, P., Mandel, M. \& Allen, R. D. (1972). Taxonomy of aerobic marine eubacteria. J Bacteriol 110, 402-429.

Bowman, J. P., Gosink, J. J., McCammon, S. A., Lewis, T. E., Nichols, D. S., Nichols, P. D., Skerratt, J. H., Staley, J. T. \& McMeekin, T. A. (1998). Colwellia demingiae sp. nov., Colwellia hornerae sp. nov., Colwellia rossensis sp. nov. and Colwellia psychrotropica sp. nov.: psychrophilic Antarctic species with the ability to synthesize

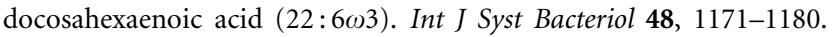

Chun, J. \& Goodfellow, M. (1995). A phylogenetic analysis of the genus Nocardia with $16 \mathrm{~S}$ rRNA gene sequences. Int J Syst Bacteriol 45, 240-245.

Chun, J., Bae, K. S., Moon, E. Y., Jung, S.-O., Lee, H. K. \& Kim, S.-J. (2000). Nocardiopsis kunsanensis sp. nov., a moderately halophilic actinomycete isolated from a saltern. Int J Syst Evol Microbiol 50, 1909-1913.
Collins, M. D. (1985). Analysis of isoprenoid quinones. Methods Microbiol 18, 329-366.

Deming, J. W., Somers, L. K., Straube, W. L., Swartz, D. G. \& Macdonald, M. T. (1988). Isolation of an obligately barophilic bacterium and description of a new genus, Colwellia gen. nov. Syst Appl Microbiol 10, 152-160.

Felsenstein, J. (1985). Confidence limits on phylogenies: an approach using the bootstrap. Evolution 39, 783-791.

Felsenstein, J. (1993). PHYLIP (phylogenetic inference package) version $3.5 \mathrm{c}$. Department of Genetics, University of Washington, Seattle, USA.

Fitch, W. M. (1972). Toward defining the course of evolution: minimum change for a specific tree topology. Syst Zool 20, 406-416.

Fitch, W. M. \& Margoliash, E. (1967). Construction of phylogenetic trees: a method based on mutation distances as estimated from cytochrome $c$ sequences is of general applicability. Science 155, 279-284.

Ivanova, E. P., Romanenko, L. A., Chun, J. \& 7 other authors (2000). Idiomarina gen. nov., comprising novel indigenous deep-sea bacteria from the Pacific Ocean, including descriptions of two species, Idiomarina abyssalis sp. nov. and Idiomarina zobellii sp. nov. Int J Syst Evol Microbiol 50, 901-907.

Jukes, T. H. \& Cantor, C. R. (1969). Evolution of protein molecules. In Mammalian Protein Metabolism, vol. 3, pp. 21-132. Edited by H. N. Munro. New York: Academic Press.

Lyman, J. \& Fleming, R. H. (1940). Composition of sea water. J Mar Res 3, 134-146.

Macián, M. C., Ludwig, W., Schleifer, K. H., Garay, E. \& Pujalte, M. J. (2001). Thalassomonas viridans gen. nov., sp. nov., a novel marine $\gamma$-proteobacterium. Int J Syst Evol Microbiol 51, 1283-1289.

Mesbah, M., Premachandran, U. \& Whitman, W. B. (1989). Precise measurement of the $\mathrm{G}+\mathrm{C}$ content of deoxyribonucleic acid by high-performance liquid chromatography. Int J Syst Bacteriol 39, 159-167.

Minnikin, D. E., O’Donnell, A. G., Goodfellow, M., Alderson, G., Athalye, M., Schaal, K. \& Parlett, J. H. (1984). An integrated procedure for the extraction of bacterial isoprenoid quinones and polar lipids. J Microbiol Methods 2, 233-241.

Saitou, N. \& Nei, M. (1987). The neighbor-joining method: a new method for reconstructing phylogenetic trees. Mol Biol Evol 4, 406-425.

Sawabe, T., Makino, H., Tatsumi, M., Nakano, K., Tajima, K., Iqbal, M. M., Yumoto, I., Ezura, Y. \& Christen, R. (1998). Pseudoalteromonas bacteriolytica sp. nov., a marine bacterium that is the causative agent of red spot disease of Laminaria japonica. Int J Syst Bacteriol 48, 769-774.

Shiba, T. (1992). The genus Roseobacter. In The Prokaryotes, 2nd edn, pp. 2156-2159. Edited by A. Balows, H. G. Trüper, M. Dworkin, W. Harder \& K. H. Schleifer. New York: Springer.

Swofford, D. L. (1998). Phylogenetic analysis using parsimony (PAUP), version 4. Sunderland, MA: Sinauer Associates.

Yi, H. \& Chun, J. (2002). Remarkable cultured bacterial biodiversity in getbol, the tidal flat of Korea. In Proceedings of the International Union of Microbiological Societies World Congresses, p. 165. Paris: IUMS.

Yi, H., Chang, Y.-H., Oh, H. W., Bae, K. S. \& Chun, J. (2003). Zooshikella ganghwensis gen. nov., sp. nov., isolated from tidal flat sediments. Int J Syst Evol Microbiol 53, 1013-1018.

Yumoto, I., Kawasaki, K., Iwata, H., Matsuyama, H. \& Okuyama, H. (1998). Assignment of Vibrio sp. strain ABE-1 to Colwellia maris sp. nov., a new psychrophilic bacterium. Int J Syst Bacteriol 48, $1357-1362$. 